\title{
DO TURISMO DAS ÁGUAS MINERAIS AO TURISMO EM ÁREAS RURAIS: A MICRORREGIÃO DE SÃO LOURENÇO (MG)
}

\section{TOURISM OF MINERAL WATER TO TOURISM IN RURAL AREAS: THE MICRO-REGION OF SÃO LOURENÇO (MG)}

\author{
Alexandre Carvalho de Andrade \\ Instituto Federal de Educação, Ciência e Tecnologia do Sul de Minas/Poços de Caldas \\ andrade.a.c@uol.com.br \\ Roberto Marques Neto \\ Universidade Federal de Juiz de Fora \\ roberto.marques@ufjf.edu.br \\ Rafael de Mello Castro Bacha \\ Universidade Federal de São Carlos \\ rafael_mello_1@yahoo.com.br \\ Enéas Rente Ferreira \\ Universidade Estadual Paulista/Rio Claro \\ eneasrf@rc.unesp.br
}

\begin{abstract}
RESUMO
As mudanças nos interesses da sociedade refletem na apropriação dos espaços urbanos e rurais para as práticas turísticas. Devido a isto, sucessivas transformações coexistem nos centros receptores de turistas, o que resulta em distintos arranjos especiais e socioeconômicos em um determinado território. Este artigo tem o objetivo de mostrar como ocorreu o processo de turistificação na microrregião de São Lourenço (MG), onde, inicialmente a atividade se desenvolveu nas estâncias hidrominerais, em ambientes urbanos, e, com a progressiva maior valorização da natureza e dos espaços rurais pela sociedade, outras localidades, anteriormente eminentemente agrárias, atualmente recebem consideráveis investimentos turísticos.
\end{abstract}

Palavras-chave: Turismo. Espaços Rurais. Desenvolvimento Regional. Sociedade. Meio Ambiente.

\begin{abstract}
Changes in society's interests reflect the appropriation of urban and rural areas for tourism practices. Because of this, successive transformations coexists in receptors tourist centers, which results in different socioeconomic and space arrangements in a given territory. The present article means to show how the turistification process happened in the micro-region of São Lourenço (MG), in which, originally, the phenomena developed itself in the springs, in urban environments, and, brought upon by the soaring importance of nature and rural spaces by society, other localities, previously exclusively agrarian, are the new focus of sizeable investments in tourism.
\end{abstract}


Keywords: Tourism. Rural Areas. Regional Development. Society. Environment.

\section{Introdução}

Em consonância a um viés sistêmico de pensamento, o ambiente é interpretado como uma visão holística das relações entre a sociedade e a natureza (ALMEIDA, 2007). Partindo da definição da autora, a Geografia atual se enquadra como a ciência que analisa as relações culturais, econômicas e sociais que se manifestam entre as ações humanas e os territórios. Este campo de interações e relações se manifesta através das paisagens, que, de acordo com Corrêa (1997), assumem uma faceta funcional e outra simbólica, sugerindo assim que é consubstanciada na interface entre fatores naturais, sociopolíticos e culturais.

Yázigi (2003) descreve a relação existente entre a paisagem e o turismo. O autor afirma que sendo a paisagem constituída por aspectos culturais e naturais, ela apresenta em seu conjunto todas as evidências de seu uso, seja através de obras monumentais e/ou através da simplicidade estética e material. Com o processo de expansão do turismo que ocorre nos mais diversos pontos do planeta, frequentemente as paisagens são apropriadas como mercadorias pela atividade turística, o que necessariamente leva a conflitos entre os moradores do lugar e os empreendedores e os novos habitantes que escolhem o centro receptor como local de morada devido a sua agradabilidade estética, sua sensação de tranquilidade, sua qualidade ambiental, dentre outros fatores (LUCHIARI, 1997; PRADO, 2003; QUINTEIRO, 2008).

Tendo em vista as diversidades naturais, culturais, econômicas e populacionais existentes no interior de uma dada espacialidade, Campanhola \& Silva (2000) afirmam que o desenvolvimento local/regional requer um planejamento espacial. Para tanto, é fundamental conhecer as diversas inter-relações existentes entre a sociedade e o território, assim como as dinâmicas internas e externas que nele atuam, para, desta maneira, oferecer subsídios para se definir as estratégias que viabilizem o desenvolvimento socioeconômico regional, em consonância com as especificidades e potencialidades existentes no território.

As dinâmicas decorrentes da expansão do turismo se pronunciam de maneiras distintas, variando de acordo com as condições culturais, econômicas, demográficas, políticas e ambientais de uma dada espacialidade. Partindo desta situação, o presente 
artigo propõe analisar as inter-relações entre a atividade turística e as dinâmicas socioespaciais em um dado território, no caso a microrregião de São Lourenço, situada no estado de Minas Gerais.

A escolha desta unidade espacial se deu pela multiplicidade de relações sociais, econômicas, culturais e ambientais que ocorrem atualmente na referida microrregião. No decorrer do último século a atividade turística se manifestou de diversas maneiras na área de estudo, refletindo, de certa forma, as transformações nos interesses e nos valores da sociedade, criando e recriando paisagens, em suas dimensões estruturais, funcionais e dinâmicas, de acordo com o potencial para seu uso mercantil e/ou para a sobrevivência dos moradores.

Pretende-se, no decorrer deste artigo, contribuir para o conhecimento geográfico acerca de temas como turismo, cultura, aspectos socioambientais e organização

espacial. É pertinente elucidar, também, que seus resultados contribuirão para a compreensão da dinâmica espacial da microrregião de São Lourenço, e para oferecer subsídios para definir estratégias para o seu desenvolvimento socioeconômico, em consonância com a conservação dos recursos ambientais e das identidades culturais de seus moradores.

\section{A microrregião de São Lourenço}

Situada na Macrorregião de Planejamento do Sul de Minas, a microrregião de São Lourenço é constituída por dezesseis municípios (Mapa 1), que totalizam 3.883 quilômetros quadrados.

Mapa 1 - Divisão político-administrativa da microrregião de São Lourenço. 


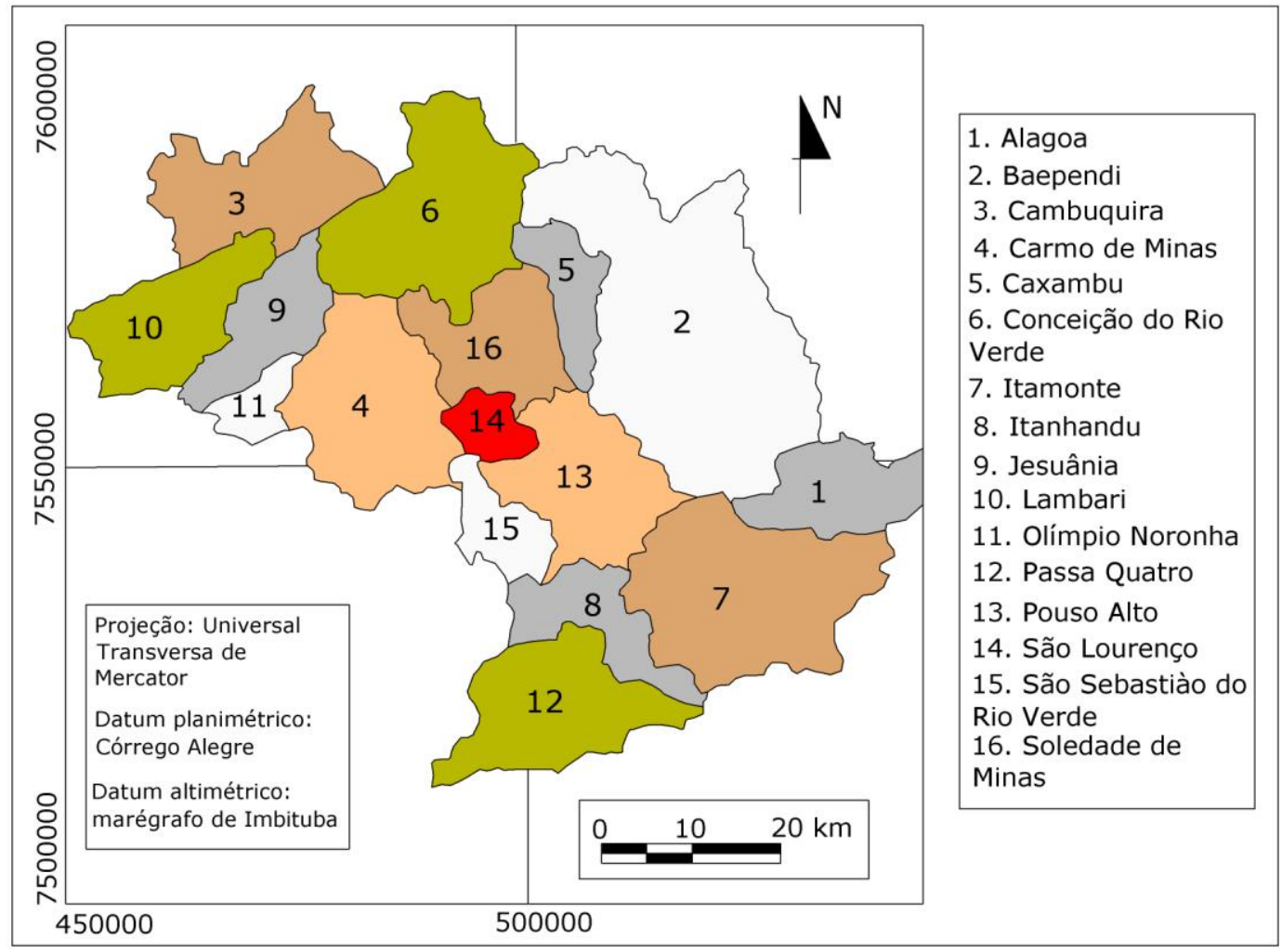

Com uma população de 208.389 mil habitantes (IBGE, 2010), a microrregião de São Lourenço apresenta consideráveis similaridades e particularidades culturais, naturais, socioeconômicas e na produção espacial entre seus municípios. O meio físico e as sucessivas ações historicamente desempenhadas pelos atores sociais que coexistem no espaço regional, contribuíram para haver municípios eminentemente urbanizados, com as atividades comerciais e de prestação de serviços fundamentais para a economia e a organização do espaço, como São Lourenço e Caxambu, mas, também, localidades onde as práticas agropecuárias são fundamentais para a população, a exemplo de Alagoa.

Em termos ambientais, a microrregião de São Lourenço proporciona um cenário de certa diversidade. A Serra da Mantiqueira apresenta evidente representatividade em considerável parcela da área estudo, e é onde se encontra a nascente do rio Verde, que, juntamente com os seus afluentes, compõe parte substancial da rede hidrográfica regional. A atenuação das temperaturas médias diárias e anuais dada pela elevação topográfica engendra sucessões fisionômicas de matas latifoliadas semidecíduas baixomontanas, alto-montanas, ombrófila mista e nebular, além dos campos de altitude que 
eclodem acima de 1800 metros de altitude. Nessas áreas mais elevadas, vinculadas aos compartimentos serranos da Mantiqueira, as declividades são mais acentuadas e a incisão vertical dos canais fluviais é mais profunda, materializando-se paisagens mais complexas em comparação às morfologias amorreadas e colinosas de declives mais modestos que avultam no baixo curso do Rio Verde.

A microrregião de São Lourenço teve o início do seu processo de povoamento, além-indígena, no século XVII, quando foram encontradas pequenas jazidas auríferas na Serra da Mantiqueira mineira (COSTA, 1994; CAVALLINI, 2001). Todavia, foi a produção de gêneros alimentícios voltados ao abastecimento das cidades mineradoras (Vila Rica - atual Ouro Preto, São João Del Rey e Congonhas) e da capital colonial (Rio de Janeiro) que possibilitou a estruturação da economia, das relações sociais e da produção espacial da região naquele período (FURTADO, 1976; RIBEIRO, 1995).

No final do século dezoito, em decorrência da decadência das atividades mineradoras, houve, em todo centro sul de Minas Gerais, um processo de dispersão populacional e de estagnação econômica, que mesmo sendo mais intenso na região "das minas", afetou também as áreas próximas, que desempenhavam a função de abastecedoras de gêneros alimentícios. Estes fatores favoreceram para a organização socioespacial em pequenas e médias propriedades familiares, produtoras de gêneros alimentícios voltados à subsistência (FURTADO, 1976; RIBEIRO, 1995). Mello Filho \& Santos Júnior (2006), descrevem que na área que hoje compreende a microrregião de São Lourenço, apenas o núcleo urbano de Baependi apresentava alta centralidade dentro da rede urbana mineira, na segunda metade do século dezenove, o que, de certa forma, ilustra o baixo dinamismo socioeconômico da região no referido período histórico.

No espaço rural regional se consolidava uma organização sociocultural e produtiva que perdura, em partes, até os dias atuais, com a formação de bairros rurais com peculiaridades típicas das sociedades “caipiras". Cândido (1964), Costa (1994) e Ribeiro (1995) as definiram como coletividades com características sociais marcantes, dentre elas, o alto grau de parentesco entre seus membros, a baixa estratificação social, a produção agropecuária envolvendo os membros da família e voltada à subsistência, a transferência da posse da terra obtida através de heranças familiares, as festividades religiosas e o sistema de mutirão como motivadores das relações sociais entre seus membros, e a considerável inércia espacial dos moradores. Diegues (2001), Cavallini 
(2001), Panzutti (2002), Mousinho (2005) e Jardim, Amâncio \& Gomes (2006) descreveram, também, a relação de simbiose entre sociedade e natureza na produção do espaço nas comunidades tradicionais, o que de certa maneira é perceptível nas comunidades mais longínquas e isoladas da Serra da Mantiqueira.

A diversidade do quadro físico, o posicionamento geográfico e as condições socioambientais existentes no território microrregional apresentam importantes condicionantes para a organização do espaço. Na área de estudo existem municípios onde o turismo historicamente apresenta importância econômica, como são os casos das estâncias hidrominerais de Cambuquira e Lambari, que passaram por processos de relativa estagnação, mas, também, localidades em que o turismo apresenta rápida expansão, especialmente nos municípios da Serra da Mantiqueira, a exemplo de Itamonte e Passa Quatro. Esta atividade econômica apresenta significativa influência nas dinâmicas regionais, porém muitas vezes atreladas a outras práticas produtivas, sejam elas no meio rural e/ou nos espaços urbanos.

\section{O processo de desenvolvimento do turismo regional e seu pretérito caráter urbano}

A partir do final do século XIX, as águas com propriedades medicinais contribuíram para o crescimento da atividade turística na microrregião de São Lourenço (GONÇALVES, 2003; ALVES, 2005; LOUSADA, 2007; FARIA, 2007; ARAUJO, 2009). Na primeira metade do século XX, o turismo apresentava influência decisiva na economia e nas relações espaciais e socioculturais das estâncias hidrominerais situadas na área de estudo, especialmente no "Circuito das Águas", composto historicamente por São Lourenço, Caxambu, Lambari e Cambuquira.

Luchiari (1998) descreve que as cidades turísticas são espacialmente organizadas para o consumo de bens, serviços e paisagens. Neste contexto, as estâncias hidrominerais receberam significativos investimentos em infraestrutura turística, como hospedarias, cassinos, parques, dentre outras, o que colaborou para o desenvolvimento do turismo nos municípios do Circuito das Águas. A rede ferroviária interligava estas referidas cidades a capital federal, naquele momento o Rio de Janeiro, o que favoreceu a histórica influência desta metrópole nas atividades turística da região em apreço.

Devido à importância do turismo, nos primórdios da vida urbana destes citados municípios, a organização do espaço urbano priorizou a disposição dos atrativos e da 
infraestrutura turística, tendo as fontes de águas minerais, localizadas nos "parques das águas", como estruturadoras da vida social e econômicas destas cidades. A crenoterapia (tratamento de enfermidades com águas minerais) foi fundamental para a atração de visitantes, que costumavam permanecer nos centros receptores por largos períodos de tempo, suficientes para a cura de enfermidades.

No decorrer do século XX, variados fatores contribuíram para transformar o perfil da atividade turística em âmbito nacional, o que refletiu diretamente nas estâncias hidrominerais. Fatores como a proibição dos cassinos e a evolução da indústria farmacêutica, que motivou a diminuição do interesse pelos tratamentos crenoterápicos, ocorreram concomitantes com a difusão de novas espacialidades turísticas e com a consequente mudança nos interesses dos turistas, o que resultou em transformações consideráveis à atividade turística no Circuito das Águas (ARAUJO, 2009).

Em visitas de campo e em diálogos com moradores da região, fica perceptível a sensação de estagnação e de decadência da atividade turística no imaginário destas pessoas, em especial no município de Cambuquira, onde vários hotéis foram fechados e seus prédios se encontram abandonados, ou adquiriram outras funções, dentre elas a de prefeitura municipal. No município de Lambari, são evidentes as precárias condições de conservação de seus atrativos turísticos, o que prejudica paisagisticamente a cidade e resulta em prejuízos econômicos.

Mesmo nas localidades onde o turismo apresenta maior dinamismo, como São Lourenço e Caxambu, há certa estagnação da atividade, e que é evidenciado pelo exíguo investimento no setor no decorrer das últimas décadas. Em contrapartida a relativa estagnação do turismo, estes centros urbanos vêm apresentando sucessiva diversificação de suas bases produtivas, provendo os moradores das localidades do entorno de serviços e produtos mais especializados.

\section{O meio rural regional e a expansão da atividade turística}

Wanderley (2001) ressalta que o espaço rural é onde coexiste a construção social resultante da ocupação do território, do uso do solo e da apropriação dos recursos naturais, mas também é um lugar de vida, onde se constroem e vivenciam as relações sociais, familiares e culturais do cotidiano. Brandão (2007) descreve que as pessoas, os núcleos familiares e as comunidades rurais vivem em espaços cujo lugar central é o 
sítio, a pequena propriedade ou a posse camponesa, e, nestes casos, sua extensão se dá através dos bairros rurais e das pequenas e médias localidades regionais.

Na microrregião analisada, há uma relativa prevalência da mão de obra familiar na produção econômica no meio rural (IBGE, 2006), porém oscilando de intensidade em âmbito intrarregional. Marafon (2006), Ferreira \& Alencar (2007) e Brandão (2007) destacam que há variadas categorias de "produtores familiares" no Brasil, coexistindo desde propriedades onde há ínfima produção de excedentes e com mínima utilização de tecnologias, até unidades familiares especializadas para o mercado.

Gomes, Baptista \& Chinelatto Neto (2005) descrevem que os processos de mecanização e as adoções de novas tecnologias variam entre as regiões e no interior das mesmas. Os fatores que resultam em tal situação são variados, sendo ambientais, econômicos ou mesmo subjetivos, como as práticas culturais e os interesses familiares. Apesar da pequena extensão territorial, no interior da microrregião de São Lourenço existem propriedades familiares que adotam técnicas tradicionais, com a produção voltada à subsistência, especialmente na Serra da Mantiqueira. Porém, há também organizações familiares altamente tecnificadas e atreladas aos mercados nacional e internacional, em especial nas áreas especializadas na produção de café, como são os casos dos municípios de Carmo de Minas e Cambuquira.

Ianni (1973), Santos \& Silveira (2001) e Marafon (2006) assinalaram que a maior parte das políticas de desenvolvimento do meio rural no Brasil contemplou as propriedades notoriamente mercantis, especialmente às voltadas ao mercado externo. Tal situação, apesar de ocasionar alguns benefícios econômicos, resultou, com intensidades regionais distintas, na proletarização dos pequenos produtores rurais, na concentração fundiária, no êxodo rural e na deterioração dos recursos naturais (QUEIROZ, 1973; RIBEIRO, 1995; WANDERLEY, 2001; GONÇALVES \& ENGELMANN, 2009).

Ferreira \& Alencar (2007) afirmam que as produções de café e de leite apresentam importância histórica para a agropecuária sul mineira, o que também ocorre na microrregião de São Lourenço. Para os autores a cafeicultura, que na área de estudo é de fundamental importância para os municípios situados em superfícies de menor altitude, conta com uma infraestrutura consolidada, como assistência técnica, beneficiamento, armazenamento e sistemas logísticos voltados à exportação. 
A pecuária leiteira na microrregião, apesar de apresentar importância econômica e cultural, tem sua produção voltada ao mercado regional e nacional. É interessante destacar a inter-relação histórica existente entre a produção de leite, a agroindustrialização e a atividade turística na área de estudos, e que é facilmente percebida nas cidades receptoras de turistas, onde são abundantes as lojas especializadas em doces e queijos produzidos em âmbito microrregional.

A partir da década de setenta e, especialmente após os anos oitenta, progressivamente os espaços rurais e os ambientes naturais passaram a ser mais valorizados pela sociedade, pelos meios de comunicação e, por consequência, pelo setor turístico. A transformação das potencialidades naturais locais em um ideal paisagístico/contemplativo, por segmentos da população urbana, é causa e efeito de uma incorporação de hábitos e valores provenientes dos espaços citadinos pela juventude rural/urbana de certas localidades. Portanto, a atuação mais efetiva dos agentes responsáveis pela intensificação do turismo representa uma incorporação de práticas exógenas às até então existentes nas localidades em questão, e, assim, a atividade turística contempla, neste sentido, estes que a tencionam como nova potencialidade local. Estas práticas agora incorporadas não representam, em si, um vetor exclusivo de transformação, mas colaboram para uma continua renovação nas questões socioeconômicas e culturais do município e/ou microrregião (DIEGUES, 2001; WANDERLEY, 2001; ROQUE, 2001; PANZUTTI, 2002; GONÇALVES, 2003; BRADENBURG，2005; TEIXEIRA，2005; MARAFON，2006; ALMEIDA，2007; SCHNEIDER, 2009). Esta situação refletiu diretamente nas dinâmicas intrarregionais da área de estudo, especialmente nos municípios situados na Serra da Mantiqueira, onde os atrativos naturais, juntamente com as particularidades da cultura e da produção do espaço, serviram como alicerces para o desenvolvimento das atividades turísticas (CAVALLINI, 2001; GONÇALVES, 2003; ALVES, 2005; FARIA, 2007).

$\mathrm{Na}$ segunda metade do século XX novas tendências globais repercutiram diretamente sobre o espaço da microrregião de São Lourenço, afetando de distintas formas suas relações econômicas, culturais e espaciais. Nas áreas de menor altitude, houve a expansão na produção e na área ocupada pelas atividades agropecuárias, notoriamente mercantis, tendo destaques a pecuária leiteira e os cultivos de café e milho (FERREIRA \& ALENCAR, 2007). Porém, na Serra da Mantiqueira ocorre um processo 
de implantação de unidades de conservação estaduais e federais, e a expansão da atividade turística. No caso da microrregião de São Lourenço há o Parque Nacional do Itatiaia, a Floresta Nacional de Passa Quatro e a Área de Preservação Ambiental da Serra da Mantiqueira, administrados pelo ICMBio (Instituto Chico Mendes de Conservação da Biodiversidade), e os Parques Estaduais de Nova Baden e da Serra do Papagaio, administrados pelo IEF (Instituto Estadual de Florestas).

Luchiari (1997), Diegues (2001), Panzutti (2002), Prado (2003) e Ferreira (2004) demonstram as multiplicidades de conflitos que permeiam as diversas esferas da vida social, tensões estas decorrentes das transformações em um dado território, e por consequência reflexionadas sobre seus moradores, especialmente os historicamente assentados em áreas marginais aos processos de desenvolvimento econômico e que apresentam satisfatórias condições de conservação ambiental, como ocorre, na microrregião de São Lourenço, com algumas comunidades rurais assentadas no entorno do Parque Estadual da Serra do Papagaio, nos municípios de Baependi e Alagoa.

Com as transformações que ocorrem nas relações entre os espaços urbanos e rurais, somadas a expansão do turismo em setores da microrregião, o aumento das práticas de atividades não agrícolas no meio rural da área de estudo é constante (ROQUE, 2001; GONÇALVES, 2003). Autores como Campanhola \& Silva (2000), Wanderley (2001), Lima et al (2005), Marafon (2006) e Schneider (2009) descrevem que a pluriatividade no meio rural são decorrentes do baixo retorno financeiro das atividades agropecuárias, frente aos novos níveis de exigência técnica e tecnológica do setor produtivo referente ao empreendedorismo agropecuário. Desta forma, atuando concomitantemente com as novas possibilidades de geração de emprego e renda, outras práticas econômicas são visadas pelos distintos atores sociais que atuam no contexto microrregional, e estas buscam correlacionar uma eminente ruralidade presente em suas construções valorativas, que se alinhem com as necessidades financeiras das comunidades em questão, dentre elas o turismo no espaço rural.

Nas proximidades das cidades de São Lourenço, Caxambu, Lambari e Cambuquira vêm progressivamente aumentando os interesses turísticos pelos espaços rurais, o que é atestado pela implantação de infraestruturas, tais como pesqueiros, pousadas, hotéis-fazenda, restaurantes e áreas de entretenimento, onde passeios a cavalo, contato com animais domésticos e a produção de alimentos são importantes 
atrativos. Já nos municípios situados na Serra da Mantiqueira, especialmente Passa Quatro e Itamonte, é crescente o turismo no espaço rural, onde os recursos ambientais, como picos, cachoeiras e fragmentos florestais, são os principais motivadores para a afluência de turistas.

Da mesma forma como ocorreu em outras regiões brasileiras, na microrregião de São Lourenço houve um considerável êxodo rural ao longo da última metade do século XX (CAVALLINI, 2001; MOUSINHO, 2005). Todavia, mais recentemente a microrregião de São Lourenço passou a receber consideráveis afluências de migrantes (AUGUSTO \& BRITO, 2008), tanto nas áreas urbanas quanto rurais (VEIGA, 2006). Carvalho (2002) descreveu que a Macrorregião de Planejamento do Sul de Minas apresenta importância considerável na entrada de imigrantes interestaduais em Minas Gerais, o que apresenta relação direta com o desenvolvimento socioeconômico regional. Porém, apesar de estar numa macrorregião com considerável desenvolvimento socioeconômico, a microrregião de São Lourenço apresenta indicadores socioeconômicos menos satisfatórios que a média sul mineira (FJP, IPEA, PNUD, 2003).

Veiga (2006) definiu, em sua análise comparativa entre as microrregiões de Minas Gerais, a área de estudo como uma região "rural atraente" para afluências de migrantes, devido ao ritmo de crescimento demográfico superior ao conjunto do estado. Em parte, isto se deve a atratividade exercida pelos municípios pertencentes ao Circuito das Águas e pelas localidades rurais com considerável conservação dos recursos ambientais, que atraem, atualmente, moradores provenientes das metrópoles de São Paulo e do Rio de Janeiro, principalmente devido as aprazíveis condições socioambientais e paisagísticas existentes na microrregião de São Lourenço.

O desenvolvimento da atividade turística e as condições ambientais regionais contribuem para a imigração interestadual, especialmente para os municípios de São Lourenço e Caxambu, principais centros econômicos regionais (ABREU et al, 2002), e para as localidades urbanas e rurais situadas na Serra da Mantiqueira. Para as áreas rurais, Brandão (2007) denominou este movimento como "comunidades neorruralizadas", pois apregoam um retorno ao modo de vida ligado à natureza. É interessante ressaltar que esta afluência de imigrantes "neorrurais" contribui para o desenvolvimento dos movimentos ambientalistas na Serra da Mantiqueira, o que, se por 
um lado traz resultados positivos, por outro pode vir a ocasionar conflitos com as práticas econômicas e culturais do uso da terra dos moradores naturais da região, já que estes imigrantes, na grande maioria das vezes, clamam pela preservação dos recursos naturais, porém recorrentemente não necessitam dos rendimentos advindos da propriedade (CAVALLINI, 2001; QUINTEIRO, 2008).

\section{As relações entre o turismo e a organização espacial regional}

A microrregião de São Lourenço apresenta importante função turística desde o final do século dezenove, quando a atividade ainda era incipiente na maior parte do território brasileiro. Apesar disso, houve consideráveis transformações socioeconômicas, demográficas, ambientais e culturais em âmbito global, nacional e regional, que afetam as práticas turísticas atuantes na área de estudos e que merecem ser analisadas.

As mutações econômicas e culturais que se sucedem em âmbito global surtem efeito, em maior ou menor intensidade, nos mais variados territórios. Com isto, novas relações são estabelecidas, o que reflete diretamente nas dinâmicas espaciais. Santos (1985) afirma que a utilização de um território ocorre através de variados conflitos entre os atores sociais que se apropriam desta espacialidade. Assim, o autor coloca que cada tipo de produção acarreta um comportamento espacial, compondo arranjos territoriais formados por frações funcionais diversas.

No caso específico da microrregião de São Lourenço, temos a "apropriação" de segmentos espaciais de acordo com os interesses distintos que atuam sobre o território, como ocorrem com os circuitos e rotas turísticas (Circuito das Águas, Terras Altas da Mantiqueira e Estrada Real), com as unidades de conservação (Corredor Ecológico da Mantiqueira e Área de Preservação Ambiental da Serra da Mantiqueira) e com a produção agropecuária (Granja Mantiqueira e Cooperativa dos Cafeicultores do Vale do Rio Verde).

Esta diversidade de apropriações do espaço reflete diretamente nas relações produtivas, políticas e socioculturais que interatuam em um território, e no caso da microrregião abordada promove resultados variados, sendo ilustrativa a relação entre a agropecuária, a paisagem, as dinâmicas socioespaciais e o turismo, como servem de exemplos as localidades de Cambuquira e Carmo de Minas. Nas duas localidades, a 
produção de café altamente tecnificada e o papel de "cidades dormitórios" se fazem presentes. Porém, enquanto em Cambuquira a economia local passou a depender da agropecuária e da migração pendular de trabalhadores para as atividades do setor secundário e terciário nas vizinhas cidades de Três Corações e Varginha, deixando o turismo em segundo plano, no município de Carmo de Minas a proximidade com São Lourenço faz com que algumas propriedades rurais se estruturem para receber turistas, tendo a produção de "cafés finos" como o principal chamariz.

O caso de Baependi também merece atenção neste processo, pois da mesma forma que as localidades citadas acima, o município apresenta importante função de “dormitório" devido à proximidade com Caxambu. Assim, esta proximidade geográfica com um importante centro receptor, atrelada a atratividade de suas paisagens naturais e de seu patrimônio construído, contribuem para aumentar o interesse pelo turismo no município, o que motiva a implantação de certa infraestrutura de apoio em Baependi. É válido ressaltar, também, que a beatificação de Nhá Chica, ocorrida em maio de 2013, motivou o crescimento do turismo religioso na referida localidade.

Esta multiplicidade de interesses, e de consequentes apropriações do espaço, não ocorre sem haver impactos consideráveis à sociedade, à economia, à natureza e às práticas culturais microrregionais. Tendo certa proximidade geográfica com os três maiores centros consumidores do país, São Paulo, Rio de Janeiro e Belo Horizonte, a área de estudos apresenta um recente processo de valorização devido às suas condições paisagísticas e culturais, que servem de alicerce ao desenvolvimento turístico, atividade importante à economia regional desde o século XIX, mas em expansão recente nas áreas rurais e de considerável conservação ambiental, como é o caso da Serra da Mantiqueira.

Na microrregião de São Lourenço, porém, os tempos e os espaços não se congregam quanto ao apogeu do turismo, já que enquanto nas localidades turísticas de desenvolvimento mais pretérito há certo desencantamento com o potencial do turismo para o crescimento econômico, em municípios anteriormente "periféricos" a atividade turística é aclamada como fundamental para a base produtiva local, sendo este processo nítido na serra da Mantiqueira, nos municípios de Itamonte, Passa Quatro e Baependi. Todavia, apesar desta considerável diversidade de interesses, há certa identidade cultural da microrregião com o turismo, e isto é perceptível na observação em estradas, cidades e espaços naturais e antroponaturais de toda a área de estudo, onde proliferam 
hospedarias, lojas de produtos locais, restaurantes especializados na gastronomia regional, áreas para práticas recreacionais, e, em consequência disto, há inúmeras placas de publicidade dos estabelecimentos turísticos.

Em programas de planejamento regional, recorrentemente o turismo é apontado como uma atividade que pode colaborar para o desenvolvimento das atividades produtivas, sobretudo em áreas de baixo dinamismo econômico, onde existem recursos propícios para a visitação, como servem de exemplos o TVA - Tennessy Valley Autority, nos Estados Unidos, em 1933, o Plan Nacional d' Aménagement du Territoire, na França, em 1950, a Cassa per il Mezzogiorno, na Itália, também em 1950; e o Plan de Estabilización, na Espanha, em 1959, (PUJADAS E FONT, 1999).

Mesmo associado como potencial para o desenvolvimento local e/ou regional, o turismo necessita de um planejamento adequado para o seu crescimento, do contrário a consolidação desta prática econômica resulta mais em prejuízos do que em benefícios aos centros receptores (KRIPPENDORF, 1989; YÁZIGI, 2003; ALVES, 2005; ANDRADE, 2005). Constituem exemplos destes danos a deterioração da paisagem, a desorganização e/ou ruptura das relações sociais e culturais dos anfitriões, a especulação imobiliária, o acúmulo de resíduos sólidos, o desmatamento, as construções em áreas inaptas, o encarecimento do custo de vida, dentre variados outros que assolam os mais diversos centros receptores de turistas no Brasil (LUCHIARI, 1997; DIEGUES, 2001; PRADO, 2003; MARAFON, 2006; ALMEIDA, 2007).

Nas áreas urbanas da microrregião analisada, a ausência de planejamento, e as consideráveis desigualdades socioeconômicas, favorecem a intensificação de impactos socioambientais, sendo prejudiciais aos moradores e a paisagem destas cidades, em especial em São Lourenço, onde há problemas como disposição inadequada dos resíduos sólidos, ausência de tratamento de esgoto e ocupações em áreas inaptas do ponto de vista físico. Estas situações devem ser melhoradas, do contrário podem afetar negativamente a atividade turística em um centro receptor.

Nos espaços rurais, em especial na Serra da Mantiqueira, o processo de turistificação e a ausência de planejamento da atividade vem resultando em impactos negativos a sociedade e aos recursos naturais. Não é incomum a disseminação de residências secundárias, hospedarias e estabelecimentos voltados ao entretenimento e as práticas recreativas em áreas de fragilidade ambiental, como topos de morro, encostas 
íngremes e margens de cursos d'água. Estes impactos, resultados do processo de crescimento do turismo, onde os recursos naturais constituem os principais atrativos, são decorrentes da nítida falta de planejamento e de gestão, seja pelas administrações municipais ou mesmo pelos órgãos públicos responsáveis pela conservação ambiental.

É importante salientar, no entanto, que concomitante a este processo de expansão do turismo, em especial nas áreas rurais da microrregião de São Lourenço, há uma notória valorização do preço das terras e, por consequência, um aumento na venda de propriedades rurais, em sua totalidade, ou uma parte. Willians (2011) já descreveu a relação existente entre a "beleza e a pureza" do campo, em detrimento das precárias condições de vida das pessoas que nele habitam. Através do exemplo inglês, o autor demonstrou os ideais idílicos acerca dos espaços rurais, marcados por belas paisagens, onde se pode cultuar a "boa vida", mas que, porém, esta situação era possível apenas para os provenientes da cidade, que usavam do campo para o descanso e a contemplação, mas não necessariamente para os pauperizados trabalhadores rurais.

Abordando o caso europeu do século XIX, Le Goff (1998) atestou que o camponês, neste referido período histórico, era depreciado em relação aos trabalhadores urbanos, vistos recorrentemente como produtores de coisas úteis e belas. A vida na cidade representava o melhor dos aspectos de "real sociabilidade" e "progresso", em detrimento do trabalhador rural, visto como rude e atrasado, desprendido do "todo em transformação" e relegado ao seu espaço "inerte". Este contexto, que refletiu intensamente no Brasil, faz com que os moradores dos espaços rurais sejam vistos como arcaicos, pobres e ingênuos, as vezes até por eles mesmos, em uma notória posição de subalternização em relação aos valores e ao modo de vida urbano-industrial, mesmo que estes, recorrentemente, busquem uma ligação com o modo de vida campesino (WANDERLEY, 2009).

Paradoxalmente, há um progressivo aumento de habitantes citadinos que migram para o espaço rural na busca da tranquilidade, da vivência junto a natureza e do modo de vida "simples"; em contrapartida, o êxodo rural de pessoas do campo que buscam na cidade uma vida moderna e mais "cosmopolita" continua significativo. Este contexto é presente no ambiente regional, em especial nos municípios da Serra da Mantiqueira, onde as condições de vida dos habitantes rurais são um tanto quanto precárias, mas, que, por outro lado, as características de suas paisagens naturais são atraentes para os turistas 
e os "neorrurais". Lefebvre (1978) citou esta situação no meio rural europeu de meados do século $\mathrm{XX}$, e atestou que frequentemente a proliferação de hospedarias e das residências secundárias contribui para o desenvolvimento do "turismo de massa", e os locais, anteriormente associados como "conservados, límpidos e puros", passam a apresentar consideráveis problemas socioambientais.

Entre a valorização da natureza e das culturas locais, o turismo vai se desenvolvendo na microrregião de São Lourenço, no Brasil, e nos mais diversos países do mundo. Brunel (2009) apontou que ocorre um processo de "disneylandização" em âmbito global, onde locais anteriormente são apropriados como originais, até serem absorvidos pela "bolha turística". Neste contexto, a natureza é apropriada e transformada, as culturas locais hibridizadas, para não dizer descaracterizadas, e o "velho paraíso virgem e puro" progressivamente se torna um local artificializado, caótico e desvalorizado.

No contexto da microrregião de São Lourenço, tanto o modo de vida rural quanto a paisagem natural já passam por um processo de apropriação pelo turismo, e, em certa medida, de maneira um tanto quanto artificial. No primeiro caso, é ilustrativa a existência de estabelecimentos turísticos, na área urbana de São Lourenço, que vendem a "vida no campo" como atração, mas que, porém, constituem pequenos sítios, onde o turista é espectador da lida rural, podendo assistir a ordenha de vacas, passear a cavalo, e realizar refeições “tipicamente mineiras”. Na serra da Mantiqueira há propriedades que divulgam a natureza como produto turístico, mas, em contrapartida, estão instaladas em áreas de preservação permanente, e notoriamente promovendo impactos ambientais.

\section{Considerações Finais}

Entre o rural que se transforma e recebe equipamentos urbanos, como hospedarias e estabelecimentos de alimentação, e as cidades que possuem suas "fazendinhas" urbanas, o turismo na microrregião de São Lourenço vai formatando novas identidades aos locais, ou, ao menos, são estas "identidades" que são comercializadas pelos investidores e mesmo pelo poder público; algo como "vivencie o natural e o rústico com todo o conforto", ou o "estando em um ambiente urbano e estruturado, passe momentos 'únicos' em uma típica fazenda sul mineira”. 
O mercado publicitário reflete a dialética do turismo contemporâneo, onde se suprime a realidade, afetando sua originalidade, o que cedo ou tarde esbarrará nas próprias limitações do produto comercializado, neste caso o espaço geográfico. Ou é possível conceber como experiência "real" se hospedar no sétimo andar de um hotel, descer de elevador, e a pouco mais de mil metros visitar uma "típica fazenda"? Da mesma forma, como se pode propagar a "vida simples" em um estabelecimento que cobra uma diária de hospedagem correspondente a um mês de salário dos moradores vizinhos, recorrentemente prestadores de serviços sazonais nestes locais?

A título de conclusão, é fundamental se elucidar que o contexto microrregional reproduz lógicas que já se propagaram em outros contextos locais, regionais e globais. Para tanto, há diversos exemplos de espaços urbanos e rurais onde, anteriormente, o turismo era associado a uma atividade econômica potencial, e pouco tempo depois era correlacionado aos problemas socioambientais que passaram a incidir nestes locais. Assim, é de se esperar que haja medidas coerentes de planejamento e gestão, que devem ser pactuadas pelos municípios, pelos órgãos públicos voltados a conservação ambiental, e, evidente, pelos mais diversos agentes sociais que interatuam nos territórios.

Em âmbito microrregional, a decadência de tradicionais centros receptores de turistas, como Cambuquira e Lambari, serve de exemplo para a eminente necessidade de interagir a valorização da cultura e da paisagem, com a satisfatória qualidade de vida dos moradores. Nestes referidos locais, a ausência de zelo com os atrativos, e mesmo de planejamento da ocupação dos espaços urbanos, motivaram seus habitantes a buscarem por novas práticas produtivas, e a potencialidade de suas paisagens e de suas fontes de águas minerais é desperdiçada pela ausência de gestões públicas mais eficientes.

\section{Referências}

ABREU, José Francisco et al. Tipologia de regiões. In: GUIMARÃES, Tadeu Barreto (coord). Minas Gerais do Século XXI, vol. II - Reinterpretando o espaço mineiro. Belo Horizonte: BDMG, 2004. pp. 253 - 296.

ALMEIDA, Maria Geralda de. Turismo e os paradoxos no consumo e conservação do meio ambiente. Ateliê Geográfico, Goiânia, v. 1, n. 2, p. 102 - 118, 2007. Disponível em http://www.revistas.ufg.br/index.php/atelie/article/view/3017/3056. Acesso em 27 de janeiro de 2014. 
ALVES, Heberton Fabrício Inocêncio. Turismo e desenvolvimento: a dimensão cultural na Serra da Mantiqueira (MG). Santa Maria: UFSM, 2005. 212 pg.

ANDRADE, Alexandre Carvalho de. Paisagem e qualidade de vida em localidades turísticas: o caso de Poços de Caldas, Minas Gerais, Brasil. 2005. 188 f. Dissertação (Mestrado em Geografia). UNESP, Rio Claro, 2005.

ARAUJO, Adriana Silva. O ciclo de vida do fenômeno turístico em São Lourenço (MG): de estância hidromineral a destino de lazer e bem estar. 2009. 177 f. Dissertação (Mestrado em Geografia). UFMG, Belo Horizonte, 2009.

AUGUSTO, Helder dos Anjos; BRITO, Fausto. O papel da mesorregião Sul/Sudoeste de Minas na migração interestadual. XVI Encontro Nacional de Estudos Populacionais. (Anais). Caxambu, Associação Brasileira de Estudos Populacionais, 2008, p. $1-20$.

BRADENBURG, Alfio. Ciências Sociais e ambiente rural: principais temas e perspectivas analíticas. Ambiente e Sociedade, Campinas, v. 8, n. 1, p. 1 - 13, 2005. Disponível em http://www.scielo.br/pdf/asoc/v8n1/a04v08n1.pdf. Acesso em 26 de janeiro de 2014.

BRANDÃO, Carlos Rodrigues. Tempos e espaços nos mundos rurais do Brasil. Ruris, Campinas, v.1, n.1, p. 37 - 64, 2007.

Disponível em http://www.ifch.unicamp.br/ojs/index.php/ruris/article/view/643/511. Acesso em 27 de janeiro de 2014.

BRUNEL, Sylvie. Turismo e mundialização: rumo a uma disneylândia universal. Mercator, Fortaleza, v. 8, n. 15, p. 7 - 18, 2009.

Disponível em http://www.mercator.ufc.br/index.php/mercator/article/view/273/221. Acesso em 27 de janeiro de 2014.

CAMPANHOLA, Clayton; SILVA, José Graziano da. Desenvolvimento local e a democratização dos espaços rurais. Cadernos de Ciência e Tecnologia, Brasília, v. 17, n. 1 , p. $11-40,2000$.

Disponível em https://seer.sct.embrapa.br/index.php/cct/article/viewFile/8860/4986. Acesso em 28 de janeiro de 2014.

CÂNDIDO, Antônio. Os parceiros do Rio Bonito. Rio de Janeiro: José Olympio, 1964. 239 p.

CARVALHO, José Alberto Magno de et al. Minas Gerais, uma nova região de atração populacional? 20 anos do Seminário sobre a Economia Mineira (1982 - 2002). (Anais). Belo Horizonte: CEDEPLAR/UFMG, 2002, p. 239 - 262.

CAVALLINI Marcelo Meirelles. Agricultura tradicional, composição paisagística e conservação da biodiversidade na região sul mineira: contribuição para o desenvolvimento rural sustentável. 2001. 205 f. Tese (Doutorado em Ciências). UFSCAR, São Carlos, 2001. 
CORRÊA, Roberto Lobato. Trajetórias geográficas. Rio de Janeiro: Bertrand Brasil 1997. $304 \mathrm{p}$.

COSTA, João Pedro de Oliveira. Aiuruoca, Matutu e Pedra do Papagaio: um estudo de conservação do ambiente natural e cultural. São Paulo: Edusp, 1994. 250 p.

DIEGUES, Antônio Carlos. O mito moderno da natureza intocada. 3.ed. São Paulo: HUCITEC/Nupaub, 2001. 169 p.

FARIA, Helena Mendonça. Alto e Médio Sapucaí: cenários para o planejamento ambiental. 2007. 201 f. Tese (Doutorado em Arquitetura e Urbanismo). USP, São Paulo, 2007.

FERREIRA, Lucia da Costa. Dimensões humanas da biodiversidade: mudanças sociais e conflitos em torno de áreas protegidas no Vale do Ribeira, SP, Brasil. Ambiente e Sociedade, Campinas, v. 7, n. 1, p. 47 - 68, 2004. Disponível em http://www.scielo.br/pdf/asoc/v7n1/23536.pdf. Acesso em 26 de janeiro de 2014.

FERREIRA, Patrícia Aparecida; ALENCAR, Edgard. Potencialidades e limitações da agricultura familiar no Sul de Minas: um diagnóstico fundamentado na abordagem interpretativa. Organizações Rurais e Agroindustriais, Lavras, v. 9, n. 3, p. 421 - 436, 2007. Disponível em http://revista.dae.ufla.br/index.php/ora/article/view/106. Acesso em 28 de janeiro de 2014.

Fundação João Pinheiro; Instituto de Pesquisa Econômica Aplicada; Programa das Nações Unidas para o Desenvolvimento. Atlas do Desenvolvimento Humano no Brasil, 2003.

FURTADO, Celso. Formação econômica do Brasil. São Paulo: Cia. Editora Nacional, 1976. $248 \mathrm{p}$.

GOMES, Adriano Provezano; BAPTISTA, Antônio José Medina dos; CHINELATTO NETO, Armando. Impactos regionais da mudança tecnológica do setor agrícola de Minas Gerais. XLIII Congresso da Sociedade Brasileira de Economia e Sociologia Rural. (Anais). Ribeirão Preto: SOBER, 2005, p. 1 - 17.

GONÇALVES, Yumi Kawamura. Perspectivas para o desenvolvimento do turismo em áreas rurais: o caso das Terras Altas da Mantiqueira (MG). 2003. $199 \mathrm{f}$. Dissertação (Mestrado em Desenvolvimento Econômico, Espaço e Meio Ambiente). UNICAMP, Campinas, 2003.

GONÇAVES, Sérgio; ENGELMANN, Sandra Andreia. A agroecologia e a reestruturação do desenvolvimento rural. Campo - Território: Revista de Geografia Agrária, Uberlândia, v.4, n.8, p. $29 \quad$ - 51, 2009. Disponível em http://www.seer.ufu.br/index.php/campoterritorio/article/view/11947/6978. Acesso em 28 de janeiro de 2014. 
IANNI, Octávio. Relações de produção e proletariado rural. In: SZMRECSÁNYI, Tamás; QUEDA, Oriowaldo. (Org). Vida rural e mudança social. São Paulo: Cia. Editora Nacional, 1973. p. 184 - 198.

IBGE - Instituto Brasileiro de Geografia e Estatística. Censo Agropecuário, 2006.

IBGE - Instituto Brasileiro de Geografia e Estatística. Censo Demográfico, 2010.

JARDIM, Anna Carolina Salgado; AMÂNCIO, Robson; GOMES, Marcos Affonso Ortiz. Racionalidade ambiental por parte de produtores rurais situados na região da nascente do rio Grande (MG). Organizações Rurais e Agroindustriais, Lavras, v. 8, n. 1, p. 105 - 116, 2006.

Disponível em http://revista.dae.ufla.br/index.php/ora/article/view/183. Acesso em 28 de janeiro de 2014.

KRIPPENDORF, Jost. Sociologia do turismo - para uma nova compreensão do lazer e das viagens. Rio de Janeiro: Civilização Brasileira, 1989. 235 p.

LEFEBVRE, Henri. De lo rural a lo urbano. Barcelona: Península, 1978. 268 p.

LIMA, Eli de Fátima Napoleão de et al. Novas identidades, novas ruralidades. Onde?. In: MOREIRA, Roberto José (Org.). Identidades Sociais. Ruralidades no Brasil Contemporâneo. Rio de Janeiro: DP\&A, 2005. pp. 41-63.

LE GOFF, Jacques. Por amor às cidades. São Paulo: Fundunesp, 1998. 159 p.

LOUSADA, Márcia. Geografia do Turismo Rural em Minas Gerais: ecos contraditórios de um segmento turístico dito em expansão. 2007. 303 f. Dissertação (Mestrado em Geografia). UFMG, Belo Horizonte, 2007.

LUCHIARI, Maria Teresa Duarte Paes. Turismo e cultura caiçara no litoral norte paulista. In: RODRIGUES, Adyr Balastreri. (Org.). Turismo - Modernidade Globalização. São Paulo: Hucitec, 1997. p. 136 - 154.

. Urbanização turística um novo nexo entre o lugar e o mundo. LIMA, Luiz Cruz (org). Da cidade ao campo: a diversidade do saber-fazer turístico, vol. 2. Fortaleza: UECE, 1998. p. 15 - 29.

MARAFON, Gláucio José. Agricultura familiar, pluriatividade e turismo rural: reflexões a partir do território fluminense. Campo - Território: Revista de Geografia Agrária, Uberlândia, v.1, n.1, p. 17 - 40, 2006. Disponível em http://www.seer.ufu.br/index.php/campoterritorio/article/view/11776/6891. Acesso em 28 de janeiro de 2014.

MOUSINHO, Mirian Gomes. Diagnóstico sócio-econômico do corredor ecológico da Mantiqueira. Belo Horizonte: Valor Natural, 2005. 58 p. 
OLIVEIRA, Lívia de. Que é Geografia. Sociedade e natureza, Uberlândia, v.11 n. 21/22, p. 89 - 95, 1999.

PANZUTTI, Nilce da Penha Miguelles. A caminho da terra: a mata. 2002. $247 \mathrm{f}$. Tese (Doutorado em Antropologia). UNICAMP, Campinas, 2002.

PRADO, Rosane Manhães. As espécies exóticas somos nós: reflexões a propósito do ecoturismo na Ilha Grande (RJ). Horizontes Antropológicos, Porto Alegre, v. 9, n. 20, p. 1 - 18, 2003. Disponível em http://www.scielo.br/pdf/ha/v9n20/v9n20a10.pdf. Acesso em 27 de janeiro de 2014.

PUJADAS, Romà.; FONT, Jaume. Ordenación y planificación territorial. Madrid: Síntesis, 1999. 399 p.

QUEIROZ, Maria Isaura Pereira de. Do rural e do urbano no Brasil. In: SZMRECSÁNYI, Tamás; QUEDA, Oriowaldo. (Org). Vida rural e mudança social. São Paulo: Cia. Editora Nacional, 1973. p. 199 - 219.

QUINTEIRO, Juliana Martins da Costa. Proteção ambiental na gestão de áreas turísticas em unidades de conservação: o caso da região de Visconde de Mauá (RJ, MG). 2008. 132 f. Dissertação (Mestrado em Engenharia Ambiental). UERJ, Rio de Janeiro, 2008.

RIBEIRO, Darcy. O povo brasileiro: a formação e o sentido do Brasil. São Paulo: Companhia das Letras, 1995. 470 p.

ROQUE, Andrea Maria. Turismo no espaço rural brasileiro: um estudo multicaso no Sul e Sudoeste de Minas Gerais. 2001. 102 f. Dissertação (Mestrado em Administração Rural). UFLA, Lavras, 2001.

SANTOS, Milton. Espaço e Método. São Paulo: Difel, 1985. 88 p.

SANTOS, Milton; SILVEIRA, Maria Laura. O Brasil: território e sociedade no início do século XXI. 3.ed. São Paulo: Record, 2001. 471 p.

SCHNEIDER, Sérgio. Ciências Sociais, ruralidade e territórios: em busca de novas referências para pensar o desenvolvimento. Campo - Território: Revista de Geografia Agrária, Uberlândia, v.4, n.7, p. 24 - 62, 2009. Disponível em http://www.seer.ufu.br/index.php/campoterritorio/article/view/11901/6961. Acesso em 28 de janeiro de 2014.

TEIXEIRA, Cristina. O desenvolvimento sustentável em unidades de conservação: a "naturalização" do social. Revista Brasileira de Ciências Sociais, São Paulo, v. 20, n. 59 , p. $51-66,2005$.

Disponível em http://www.scielo.br/pdf/rbcsoc/v20n59/a04v2059.pdf. Acesso em 27 de janeiro de 2014. 
VEIGA, José Eli. A configuração territorial de Minas Gerais. XI Seminário sobre a Economia Mineira. (Anais). Diamantina: Cedeplar/UFMG, 2004, p. 1 - 20.

WANDERLEY, Maria Nazareth Braudel. A ruralidade no Brasil moderno. Por un pacto social pelo desenvolvimento rural. In: GIARRACCA, Norma. (Org). ¿Una nueva ruralidad en América Latina?. Buenos Aires: Consejo Latinoamericano de Ciencias Sociales, 2001. p. $31-44$.

Disponível em http://bibliotecavirtual.clacso.org.ar/ar/libros/rural/wanderley.pdf. Acesso em 27 de janeiro de 2014.

O mundo rural como um espaço de vida reflexões sobre a propriedade da terra, agricultura familiar e ruralidade. Porto Alegre: Edufrgs, 2009. 330 p.

WILLIANS, Raymond. O campo e a cidade na história e na literatura. São Paulo: Companhia das Letras, 2011. 531 p.

YÁZIGI, Eduardo. Civilização urbana, planejamento e turismo. São Paulo: ed. Contexto, 2003. 359 p.

Artigo recebido para publicação em junho de 2014.

Artigo aceito para publicação em novembro de 2014. 